\title{
INVESTMENT STRATEGIES APPLIED DURING THE MASS PRIVATISATION WAVE IN CENTRAL AND EASTERN EUROPE: THE CASE OF BULGARIA*
}

\author{
Emanuela Todeva \& Veselin Kuntchev
}

\begin{abstract}
The aim of this paper is to look at the results from the mass privatisation in Bulgaria as one of the basic pillars of structural reform. A database from the first wave of the mass privatisation was used for the secondary analysis of the investment strategies of the Bulgarian privatisation funds.

We grouped the 82 Privatisation Funds registered in Bulgaria in 4 groups according to their invested capital: Large Funds, Medium, Small and Micro Funds, and we analysed their investment strategies, employed during the three auctions for mass privatisation. Particular attention was paid on the analysis of their industrial and locational participation, along with their interest in firms of different size and varying control opportunities.

A typology of privatised firms by size, main shareholders, market share and industries reveals a complex picture of restructuring of ownership and industrial linkages. Special attention is placed on the analysis of the use of specific financial instruments, such as privatisation bonds. Our comparrison of the mass-privatisation programmes in Poland, the Czeck Republic, Russia and Bulgaria reveils similarities and unique features in each country.
\end{abstract}

\section{Introduction}

Privatisation and de-regulation are a global phenomenon and could be defined as one of the fundamental features of contemporary economic policy. The trend is for the state to withdraw from direct management of firms and services, and to adopt primarily regulatory and control functions. The protective role of the state is reduced and the distribution of public goods, as well as the allocation of resources, is left mainly to a 'free' market mechanism.

According to Welfens and Jasinski (1994), the transition from a Socialist economy to a Market economy in Central and Eastern Europe involves seven building blocks. These are: a) price liberalisation and decentralisation of the state; b) macro-economic stabilisation; c) privatisation; d) foreign economic liberalisation (for imports, exports and foreign direct investment); e) demonomolization and deregulation of stock markets and the creation of capital markets; f) a change of attitudes to embrace capitalist values; g) a change in the role of government in the policy making process. This transition policy agenda aims to transform the entire social system to resemble developed market economy.

In the context of Central and Eastern Europe (CEE), the privatisation program was seen as a fundamental commitment by governments to achieve irreversibility of the changes, and to establish the foundations for industrial restructuring in a free market environment. This paper

\footnotetext{
* Presented at the VI World Congress of the International Council For Central \& East European Studies, ICCEES, 29 July - 3 August, 2000, Tampere, Finland
} 
aims to compare the frameworks for mass privatisation programs in a number of CEE countries, and to analyse in depth the institutional environment for mass privatisation, the introduction of new financial intermediaries (Privatisation Funds), and the investment strategies, adopted by the latter in Bulgaria.

Our analysis of the investment strategies applied by the privatization funds in Bulgaria highlights the relationship between the size of the Investment Funds and their strategic choices during the three auctions of the mass privatisation (1997-1998). This secondary analysis of investment strategies applied by the Privatisation Funds in Bulgaria is based on a Council of Ministers database (Results from the First Wave of Mass Privatisation, 1998).

\section{Mass Privatisation Programmes in Central and Eastern Europe}

The diverse methods for mass privatisation of the state-owned enterprises in Eastern Europe have the purpose to achieve several key objectives: social justice, establishment of economically independent and competitive business subjects that are capable to mobilise and to manage effectively the available resources, and introduction and development of capital markets. In general, three methods of privatisation were used. Restitution (or the restoration of the ownership upon the appropriated in the past assets) was conducted in the Czech Republic and Bulgaria. The implementation of this method is connected most of all with the achievement of social justice, and these measures do not lead to considerable structural changes in the economy. Cash privatisation, where the state offers production assets for sale to local and foreign investors, was conducted in Hungary, Poland, the Czech Republic, Bulgaria, and Romania. Apart from the establishment of independent economic units, and a partial restructuring of the national debt, the cash privatisation facilitated primarily foreign investment in firms with dominant market position. This form of privatisation rarely led to a large scale restructuring, or increased competition in the selected industrial sectors. Mass privatisation (or privatisation by means of investment bonds, or analogous non-interest state issued securities) was implemented in the Czech Republic, Poland, Russia, Bulgaria, and many of the former Soviet republics (Simoneti, Estrin, Bohm, 1999).

The main objectives in the use of investment privatization funds and unique quasi-money instruments of payment (investment vouchers) as financial intermediaries as part of the Mass Privatisation were:

- To encourage the ownership of shares among the broad layers of the population, to diversify the investment portfolios and to reduce the risk for small investors;

- To stimulate the development of the financial markets through investing in securities by the population and through the emergence of investment intermediaries and institutional investors;

- To avoid excessive fragmentation of the ownership;

- To establish as soon as possible a new corporate management system;

- To achieve a more effective management of the firms.

It is clear that the mass privatisation did not aim to improve the investment climate for the firms, and therefore, it stimulated an opportunistic and rent-seeking behaviour among the investors. Among the basic reasons for using different types of securities instead of money is the lack of sufficient liquidity assets among the population, the demand for social justice, and others. 
The debates on the legal framework for mass privatization were driven by the two main models: the Anglo-Saxon model, aiming at enhancement of the external control through trading of shares on the stock market, and the German model, with its emphasis on the internal control by shareholders and voting (Simoneti, Estrin, Bohm, 1999). The design of the IPFs as financial intermediaries aimed to adopt features from both models in order to establish new mechanisms for corporate governance in the economy. The efforts to develop new forms of corporate control in the economy on a massive scale, however, were not supported by sufficient emphasis on the regulation of the IPFs.

The institutional structure of the privatization funds was in many respects not appropriate for their tasks to supervise the restructuring of the firms. The adopted form of closed-end diversified institutional investors gives very limited incentives to fund managers for the active and efficient restructuring of their portfolio, and at the same time does not provide conditions for strict accountability of fund's managers.

In most transition economies the privatisation involved the following: a transformation into a joint-stock company, direct sale to a predetermined buyers, restitution, distribution of vouchers to the public, public auction or public tender, unpaid transfer to municipal property and social security and health insurance, or a combination of these methods.

The lack of active stock markets and securities markets, the lack of experience by shareholders and regulators, the complicated mixture of privatization methods, the delayed and vague legislation regulating the activities of the IPFs allowed by law multiple forms of opportunistic and rent-seeking behaviour by fund managers. This situation shaped very much their investment strategies. The positive results in Poland as exception could be explained with the strong supervision of fund managers by the sponsoring organizations, and with the strong regulation by the state.

Our brief comparison between the Bulgarian framework, the Czech model of voucher privatization, The Polish and the Russian cases highlights the differences and similarities in the adopted approaches.

\section{The Czech Model of 'Voucher' Privatisation}

The legal framework for the Czech voucher privatization was established in 4 steps: a) Law on Joint Stock Companies (1990); b) Commercial Code (1991); c) Law on the Conditions of Transferring State Property to Other Persons (1991) and by-Law on the Issue and Use of Privatisation Vounchers (1991) with its amendments in 1992; d) The Regulation on Investment Corporations and Investment Funds (1992) - two months after the deadline for registration of IPFs (Kotrba, Kocenda, Hanousek, 1999).

The voucher scheme was launched in the context of already started restitution and small scale privatization. Within its framework, a legal opportunity was established for all Czech citizens over 18 years of age to participate directly in the purchase of one or several enterprises, or to exchange their vouchers for shares in IPFs. During the two waves of the Voucher Privatisation, 350 IPFs were registered. The first 13 of them took control of over 40 percent of the emitted vouchers (Jezhek, T., 1995).

The Investment Funds in the Czech Republic were of closed type, with the following specifications:

- they have no right to invest in more than $20 \%$ of the shares in each privatised enterprise;

- in the event when one privatisation manager controls several Funds, the total share participation of these Funds into one enterprise could not exceed 40 percent; 
- the Investment Funds could not perform banking activities;

- the shares of the Investment Funds could be freely provided for sale, nevertheless their liquidity is quite low.

This regulatory framework for the activities of the Investment Funds as new financial intermediaries makes explicit the Government efforts to establish a diverse shareholding structure, and to prevent direct appropriation of production assets by single private investors. The large number of registered Investment Funds initially was due to the very minimal required authorised capital. Later on, the limit was raised up ten times with the objective to prevent the property from partitioning

Initially, during the first wave 1491 enterprises with total balance value of USD 10.6 billion were offered for privatisation. In about 400 enterprises the demand exceeded the supply. In general, the investors expressed interest in small and medium size enterprises - mainly in food and in tourism industry (Jezhek, T., 1995, Kotrba, Kocenda, Hanousek, 1999). As a result of aggressive advertising campaign on the side of the investment funds and the supply on the side of the individual investors, the Investment Funds attracted $72 \%$ of the value of the vouchers, possessed by citizens.

By March 1, 1995 when the last wave of the privatisation was performed, $60 \%$ of the voucher points were concentrated in the Investment Funds, and about 30\% in banks and in the Czech Insurance Company. The prevailing part of the privatisation property came into the ownership of Investment Funds, controlled by large state-owned banks. The state owns the control packages in four of the leading banks that comprise $75 \%$ of the assets of the Czech banking system. This 'quadro' controls also the leading Investment Funds, as well as a great deal of smaller banks. At the end, the state remained virtually the proprietor of the greater part of the Czech economy.

In an interview for the media, Yan Mladek, director of the Czech Institute of Applied Economics, stated that most of the subjected to privatisation enterprises did not improve their status, and in some cases it got even worse ('Pari' weekly, No.41, Nov.28, 1997). According to a number of publications, the mass privatisation in the Czech Republic did not change fundamentally the structure of the economy. Results from a survey with the Czech IPFs shows that the main motive of the investors was 'value maximisation through active portfolio trading and optimisation' (Kotrba, Kocenda, Hanousek, 1999, p.39). The acquisition of assets therefore was driven by rent-seeking motives rather than to expand the economic activities of the firms.

\section{The Privatisation in Poland}

The Polish mass privatisation was oriented towards the maximisation of the economic efficiency and stability. Fifteen National Investment Funds (NIF) were established, with the main objective to assist the structural reform of the Polish economy. Each Fund was organised as a joint-stock company, or an Investment Fund of closed type.

Within the established framework, each fund is controlled by a Supervisory Board, which represents the interests of the investors. The investors comprise of all Polish citizens over 18 years of age that have purchased the so-called Universal Shareholder Certificates (USC). They are issued to a bearer and could be traded freely between the citizens or at the Warsaw Stock Exchange. Members of the Supervisory Board were appointed subject to their competency. The selection was conducted by a special state Selection Commission, and approved by the Prime Minister. 
The managers of these Investment Funds have as an assignment, both to perform their everyday administrative functions, and to assist the enterprises in achieving access to capital funds new technologies and markets. The Supervisory Board signed a Contract of Management Agreement with the investment managers for a term of 10 years.

On the contrary to the Czech model of free choice of participation and auction supply of the shares, in Poland the shares of the included into the Privatisation Program enterprises were distributed by the state, subject to the following scheme:

- 33\% of the shares from each firm to be held by leading National Investment Fund;

$-27 \%$ of the shares to be distributed evenly between the other Investment Funds;

$-15 \%$ of the shares to be distributed free of charge to the workers;

$-25 \%$ to be retained by the state treasury (Lewandowski and Szyszko, 1999).

The investment policy of the Funds was oriented towards the increase of the market value of their shares.

As a result of the Polish program for mass privatisation three types of shares could be transacted at the stock exchange, and respectively to be accumulated into the investment funds. These are the Universal Shareholder Certificates, shares of subjected to privatisation enterprises, and shares of the Polish National Investment Funds.

However, the total value of the assets of the included into the scheme enterprises did not exceed $5 \%$ of the total value of firm assets from the Polish industry. To accelerate, and to activate the process of privatisation, the Polish Selection Commission allowed foreign investors to the Warsaw Stock Exchange (Lewandowski, J., Szyszko, R. (1999).

After the end of the first year of the mass privatisation process, the shares of the NIFs were allowed to be traded at the Warsaw Stock Exchange, or to be traded to strategic investors, and to be stored as long-term investments. This created a mixed framework of incentives - both for rent-seeking and for expansion of economic activities.

\section{The Russian Voucher Program}

The Russian Voucher Program is distinguished by both the excessive complexity, and the contradictions between objectives and results. The idea about the voucher privatisation was set in a Presidential Decree of 1992. Among the main objectives of the Russian program were the fast transformation of the public property into private one driven by the principles of social justice. Three years following the distribution of the first vouchers, the Russian authorities stated out, that $80 \%$ of the state-owned property is in private hands.

The vouchers were distributed almost free of charge through the branches of Sbergbank (the Russian State Savings Bank). They could be transacted free of charge, and this was one of the main reasons for the rapid growth and development of a secondary market for these securities. Almost right away with the appearance of the first vouchers a large number of Investment Funds were established, proposing professional intermediary. Under the conditions of the lack of strict regulatory regime, a great number of Investment Funds made non-realistic promises, and succeeded to acquire considerable part of the vouchers of the population.

The rights that were granted to the citizens to trade the freely acquired vouchers, provided an opportunity for concentration of the management of the enterprises into the hands of the active institutional investors, like the Investment Funds. On the other side the personnel of the enterprises also had the opportunity to purchase up to $51 \%$ of the shares of its enterprise, under preferential conditions. 
The purchase price of the enterprises was defined by means of multiplying their book value by the factor of 1.7. Towards the end of the Voucher privatisation over $60 \%$ of the shares of privatised enterprises turned out into the hands of the workers or the management teams.

Besides that, the investment funds were not allowed to acquire more than $10 \%$ of the shares in individual enterprise. In this way, they were deprived of the opportunity to appoint by themselves the management bodies of a particular company, and to bear the responsibilities respectively. The strategic investors in the Russian economy remained the former managers and workers' collectives, and their main strategies remained the preservation of the firm and the employment status of people, and rent-seeking activities.

\section{The Mass Privatization Program in Bulgaria}

The mass privatization in Bulgaria actually starts in 1997 and is expected to end in 2001. It is conducted in two basic stages. The first one covers the period 1997-1998, and the second one 1999-2001. This paper reports data only from the first part of the Mass Privatisation Programme. The Program was developed with a view to accomplish the following main objectives:

- to make a sudden change in the process of privatisation: the targets of the Program were mostly the large and medium-size state-owned enterprises.

- to involve in the process of transformation of the state property the citizens of Republic of Bulgaria and to give them the opportunities to participate in the management of the transformed property;

- to conform the long-term structural policies in the specific context of current economic objectives, which includes a) improvement of the state budget; b) improvement of the management of the state sector; c) reduced and more clear investment priorities for the state.

The scheme anticipated part of the citizens to participate as investors in the process of privatization individually. However, the greater part were expected to participate through the established by law new type of investment intermediaries - the Privatization Funds (PF).

\section{Legal Framework for the Privatization in Bulgaria}

The legal basis of the privatization process in Bulgaria is the 'Law for transformation and privatization of the state and municipal enterprises' and the supplementary under-law acts (1992). It was adopted by the Parliament in 1992 and was amended several times after that. The Law establishes the framework for the whole privatization process in Bulgaria by settling all possible methods of privatization. In order to accelerate the privatization process in Bulgaria, in 19996 the National Assembly ratified two programs - for cash privatization (SG issue 46/1996) and for mass privatization (SG issue 1/1996). The main methods are: Auctions; Negotiations with prospective buyers; Public offering of shares; Leasing agreements. The payment is made either in cash or as a combination of cash payment and swaps of debt-against-property.

The leading institutions in the privatization process were the following: the Council of Ministers, the Privatisation Agency, the Center for Mass Privatisation, Registration Bureaus, and Privatisation Funds.

The Bulgarian legislator has defined the Privatisation Fund (PF) as a special form of Investment Company (IC), with basic activities to acquire shares from the enterprises, included into the list for mass-privatisation, and to participate in the firm's governance structure. The privatization funds in Bulgaria are founded under the initiatives of private legal entities (natural or juridical persons - as in the cases of the Czech Republic, Russia and Ukraine). This is in contrast with Poland and Romania, where the state plays the leading role. 
- The Council of Ministers prepares a listing of enterprises whose privatization is prohibited, except for under its explicit decision.

- The Privatization Agency, established in the fall of 1992, is responsible for the preparation of the annual Privatization program and for the organization and sale of the large state-owned enterprises to private investors.

- The Center for Mass Privatization (CMP) is responsible for the preparation and the accomplishment of the mass privatization program. It is established in the summer of 1994 as an independent governmental organization.

- Registration Bureaus - the accomplishment of all stages of the mass privatization is performed with the participation of the post offices. They issued the voucher books, announced the required information, submitted information to the regional centers for mass privatization, responded to the questions of the citizens, performed the transfers of the vouchers, and accumulated the bids for the auctions. More than 3000 post offices all over the whole country were involved in the mass privatization process

- The Privatisation Funds could use the collected Investment Bonds to acquire shares of the enterprises, included into the list for mass privatisation. Within six months after the completion of the last centralised tender, the Privatisation Funds could terminate their activities as investment companies, and transformed into holding companies.

The participation of the voucher holders in the mass privatization through the intermediation of $\mathrm{PF}$ is shown on the following Figure 1.

Figure 1: Institutional Framework for Privatisation

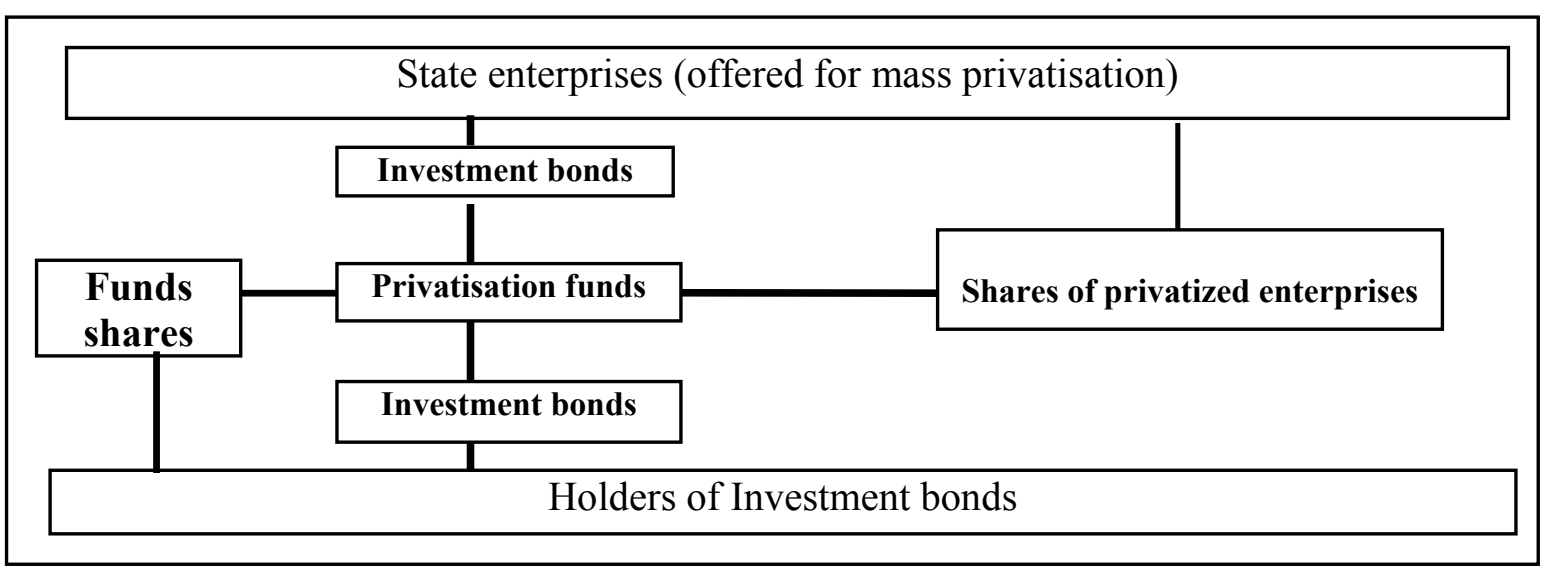

The investment bonds are the basic instrument used for purchase of shares of companies included in mass privatisation list. Subject to the Bulgarian law the investment bonds are specified as non par value, non-interest incurring securities with nominal value of one Investment Bulgarian Lev (IBGL 1). Neither of the quotations of the privatisation bonds on the secondary market (as far as such market is possible at all, subject to the severe restrictions, imposed upon the transfer of bonds), nor the inflation, or any other similar factor could have an impact upon the value of the IBGL. Subject to the provisions of the Privatisation Funds Act, one IBGL is equal to one BGL.

The investment bonds do not hold the typical characteristics of securities. Their Emitting Agent is the state. Thus they are a type of state securities. The main objective of the investment 
bonds is to provide the opportunity to the citizens to receive relative reimbursement on the basis of the created assets by the means of their own labour. Each Bulgarian citizen with permanent residence in the country, who has completed 18 years of age and the children, that have one or both of the parents deceased, have the right to acquire Investment Bonds, and to use them to purchase shares directly from the companies, included into the list for mass privatisation, or to invest them in a Privatisation Fund in exchange for shares from the Investment Portfolio of the Fund. In other words the investment bonds could be considered as particular type of convertible obligations (convertible bonds), that could be possessed by a particular type of beneficiaries.

The shares of the companies, which are included in the list for mass privatization, are to be exchanged for investment vouchers during centralized auctions. The Bulgarian citizens having the right to participate in the mass privatization can directly compete for the shares of the companies or transfer their investment voucher to privatization funds.

The enterprises, included in the Mass Privatization Program, are selected on the following criteria:

- Companies, which do not pertain to strategic economic branches and activities;

- Companies with satisfactory financial statements for the previous year:

- Capitalization of assets ration $>15 \%$,

- Net value of capital to real assets ratio $>40 \%$,

- Net value of capital to fixed capital ratio $>0.6$;

- Companies, which are among the biggest state-owned enterprises, with balance value of the long-term assets over $50 \mathrm{Mln}$ BGL. (approximately USD 700000 according to the exchange rate as of the date of the preparation of the list);

- Companies, which are not monopolies in the respective branches.

Table 1.: Enterprises for Mass Privatization under Ministries/ Committees

\begin{tabular}{|l|c|c|c|}
\hline \multicolumn{1}{|c|}{ Branch Ministry } & $\begin{array}{c}\text { Number of } \\
\text { firms }\end{array}$ & $\begin{array}{c}\text { Total registered } \\
\text { capital (MIn. leva) }\end{array}$ & $\begin{array}{c}\text { Offered equity for mass } \\
\text { privatisation (mIn. leva) }\end{array}$ \\
\hline Ministry of Industry & 651 & 158,897 & 71,069 \\
\hline $\begin{array}{l}\text { Ministry of Trade and Foreign } \\
\text { Economic Cooperation }\end{array}$ & 27 & 12,730 & 3,458 \\
\hline $\begin{array}{l}\text { Ministry of Regional Development } \\
\text { and Construction }\end{array}$ & 70 & 7,495 & 4,515 \\
\hline $\begin{array}{l}\text { Ministry of Agriculture and Food, } \\
\text { Wine and Tobacco Industries }\end{array}$ & 167 & 13,458 & 7,117 \\
\hline Ministry of Transportation & 73 & 4,659 & 2,516 \\
\hline Ministry of Culture & 2 & 934 & 5,576 \\
\hline Committee of Tourism & 54 & 19,229 & 121 \\
\hline Ministry of Energy & $\mathbf{1 , 0 5 0}$ & $\mathbf{2 1 6 , 4 7}$ & $\mathbf{9 4 , 8 5}$ \\
\hline Total & 6 & 163 & \\
\hline
\end{tabular}

The list of enterprises to be privatized by investment vouchers includes also those enterprises for which negotiations for cash privatization have been initiated. The cash investors have the opportunity to buy considerable shares of the larger companies after deducting the 
portion for mass privatization, the restitution claims and the preferred stock. The investor could complement his property by purchasing shares of a certain company on the secondary market and/or by additional buy-out of the remaining state-owned stock.

According to the above-mentioned criteria 1050 enterprises with total value of assets 216,47 billion BGL were selected (Table 1.). The participants have the following opportunities:

- to transfer their vouchers to a privatization fund and to become shareholders of the latter;

- to transfer the investment vouchers to their relatives;

- to participate directly in the centralized auctions and to purchase shares from the privatized companies.

\section{The Privatisation Process}

The acquisition of shares of the privatized enterprises is performed by centralized auctions. Before each of them and according to a mechanism, approved by the Council of Ministers, the minimal price of the shares of each enterprise is determined by administrative means. For each auction the participants submit closed bids, which after the expiration of the stipulated period are opened and ranked according to the prices bidden. The offers are satisfied starting from the highest prices until the allocation of all shares. The participants with unsatisfied bids receive back their vouchers and may use them on the following auction.

The foreign investors have the opportunity to participate in the process of mass privatization through privatization funds. Thirteen of the funds have foreign founders. The third in size fund in the country is founded by ING Bank, the latter of which operates in the country since 1994.

The managers and the employees of the enterprises, subject to privatization, obtain special preferences, which is stipulated in the privatization laws. In the Mass Privatization Program, the persons, who meet this requirement may acquire for free up to $10 \%$ of the shares, offered for privatization, and in the cash privatization they have the right to buy (at a discount of 50\%) up to $20 \%$ of the state-owned shares.

In the context of this broad institutional framework, one of the most interesting questions is the strategic behaviour of the privatisation funds in Bulgaria. Our analysis aimed to discover to what extend these funds acted as investment companies, and what were the main features of their investment portfolios.

\section{Analysis of the Investment Strategies of the Privatisation Funds in Bulgaria}

The enterprises offered for privatisation in the mass privatisation program are classified in three main groups according to the share of the equity provided for privatization:

- stock capital for privatisation equal up to $25 \%$ of the state interest. These are big enterprises important for the economy of the country and in which the state keeps the majority share, or is looking for to a strategic investor;

- stock capital for privatization between 25 and $70 \%$ of the state interest. These are large and middle-sized enterprises. The reserved state share is either kept for restitution claims of large amounts, or, as is in most of the cases, the state plans to withdraw gradually from these enterprises and to find investors through the cash privatization;

- stock capital for privatization between 80 and $90 \%$ of the state interest. These are small and medium size enterprises, which are not provided $100 \%$ for privatisation because of considerations of restitution claims. 
In practice, presently the privatisation funds restrict themselves to investments in shares of the privatized enterprises $95-99 \%$ of their stock. This was due to the fact that for the investments in Treasury Bills or bank deposits they need fresh money. So, they did not have the resources. What is currently allowed to the privatisation funds is investment in securities of other issuers, but admitted for trade at the stock market. Thus, the ability the privatisation funds have for diversification of their portfolios by using different instruments was highly limited.

During the privatisation low interest was shown in the branches of the heavy industries machinery construction, electronics and metallurgy. The enterprises offered from these branches and subject to privatization are bigger and require the investment of more vouchers. From another point of view, only $25 \%$ of the shares of the bigger enterprises were privatized. These minor stakes were not of interest, because almost all of the funds strived for acquiring larger stakes in order to take stronger control over enterprise.

For our analysis we have used data and publications isued from Center for Mass Privatisation, Sofia (1998). We look at all 82 registered privatisation funds that took part in the mass privatisation program, and we analyse their investment strategies employed during the three waves of mass privatisation. In order to determine their strategies, we calculated the following indicators:

- total value of offered shares for the mass privatisation program (in thousand leva);

- total number of acquired shares during all three privatisation waves;

- total number of firms in which shares have been acquired;

- concentration of shares per firm - as an indicator

- total number of shares in control firms (or firms where more that $50 \%$ of the firm's shares are offered for sale);

- total acquired shares in firms for asset management (where a stake of $10 \%$ has been obtained, as this is a significant stake, which gives an opportunity to influence company management, or could be sold, or exchanged in a secondary market for securities);

- total number of shares acquired in small firms (with book value up to $200 \mathrm{mln}$ leva);

- total number of shares acquired in medium firms (with book value between 200 and $800 \mathrm{mln}$ leva);

- total number of shares acquired in large firms (with book value above $800 \mathrm{mln}$ leva);

- total number of shares acquired in on district;

- total number of shares acquired in one industry.

In addition to that, we grouped all privatisation funds into 6 groups according to their invested capital, or the total number of acquired shares (Table. 2). While there is an overlap between the number of enterprises in which funds have acquired shares in each of the six groups, there is a general correspondence between the size of the fund and the number of targeted firms. 
Table 2. Typology of Privatisation Funds

\begin{tabular}{|l|l|l|l|l|}
\hline \multicolumn{1}{|c|}{ Groups } & \multicolumn{1}{|c|}{$\begin{array}{c}\text { Acquired } \\
\text { Shares }\end{array}$} & \multicolumn{1}{|c|}{$\begin{array}{c}\text { Number of } \\
\text { firms }\end{array}$} & $\begin{array}{c}\text { Exceptions from the group } \\
\text { trend }\end{array}$ & \multicolumn{1}{|c|}{$\begin{array}{c}\text { Value of the targeted } \\
\text { stock }\end{array}$} \\
\hline Large Funds & $1-6$ million & in 34-97 firms & $\begin{array}{l}\text { Doverie - 174 firms } \\
\text { Bulgarian-Dutch Fund -111 } \\
\text { firms }\end{array}$ & $\begin{array}{l}\text { invested capital in firms } \\
\text { worth between 40-70 } \\
\text { billion leva. }\end{array}$ \\
\hline Medium Funds & $\begin{array}{l}200-700 \\
\text { thousand }\end{array}$ & in 9-43 firms & & $\begin{array}{l}\text { invested capital in firms } \\
\text { worth between 15-35 } \\
\text { billion leva }\end{array}$ \\
\hline Small Funds & $\begin{array}{l}100-199 \\
\text { thousand }\end{array}$ & in 6-18 firms & $\begin{array}{l}\text { Otechestvo-61 firms } \\
\text { Bulgarleasing- 58 firms } \\
\text { South-Eastern - 30 firms }\end{array}$ & $\begin{array}{l}\text { invested capital in firms } \\
\text { worth between 1-5 } \\
\text { billion leva }\end{array}$ \\
\hline Micro Funds & $\begin{array}{l}20-99 \\
\text { thousand }\end{array}$ & in 2-12 firms & $\begin{array}{l}\text { Rodina - 22 firms } \\
\text { invested capital in firms } \\
\text { worth between 100-970 } \\
\text { million leva }\end{array}$ \\
\hline
\end{tabular}

There are also exceptions, where funds have acquired shares in much higher number of firms that the rest of funds in their group (see Table 1.). There is a more clear division between the four groups of funds in relation to the targeted stock. Large funds have targeted stock in firms worth between 40-70 bln leva, while the rest of the funds have acquired shares in smaller firms. The group of medium size funds have targeted firms worth between 15-35 billion leva. Small funds have targeted on average small firms worth between 1-5 billion leva and micro funds have targeted stock in small firms worth between 100-970 mln leva. All data calculated for acquired shares in firms according to size of the stock uses this typology of funds (see Table 2.). Using the database we looked at the types of the firms offered for mass privatisation. In our typology of firms offered for sale in the mass-privatisation program we identify 4 groups (Table. 3 ).

Table 3. Typology of Privatised Firms through Mass Privatisation

\begin{tabular}{|l|l|l|l|}
\hline Type of firm & Value of stock & Sold Shares & \% of total traded shares \\
\hline Large Firms & $\mathbf{8 0 0 m I n}-18$ bln leva & $21,823,073$ & $31.6 \%$ \\
\hline Medium Firms & $200-800$ mln leva & $21,376,869$ & $30.9 \%$ \\
\hline Small firms & $50-200$ mln leva & $19,306,287$ & $27.9 \%$ \\
\hline Micro firms & $1-50$ mln leva & $6,625,609$ & $9.6 \%$ \\
\hline Total: & & $69,131,838$ & $100 \%$ \\
\hline
\end{tabular}

After numerous interpretations of the data, we define the following expected strategies for testing (Table 4.).

\footnotetext{
${ }^{1}$ This group include 3 extra-large funds (Doverie, Bulgarian-Dutch, and AKB Forest-Invest, with acquired shares between 4-6 mln. leva) and the group of Total Citizens $-10 \mathrm{mln}$ leva.

${ }^{2}$ This group includes two sub-groups (large firms $800 \mathrm{mln}-7$ bln leva and 2 extra-large firms with offered stock for 13 and 18 bln leva respectively).
} 
Table 4.: Investment Strategies

\begin{tabular}{|c|c|c|}
\hline INDICATOR & STRATEGY & DESCRIPTION OF CALCULATIONS \\
\hline CONC & Strategy for concentration of assets & $\begin{array}{l}\text { Funds that have acquired above the average for } \\
\text { the total group shares / per firm }\end{array}$ \\
\hline MAN / AM & Strategy for asset management & $\begin{array}{l}\text { Over } 80 \% \text { of total acquired shares are in firms } \\
\text { where more than } 10 \% \text { of shares are acquired by } \\
\text { the fund }\end{array}$ \\
\hline CONTR / C & Strategy for control & $\begin{array}{l}\text { Over } 80 \% \text { of acquired shares are in firms where } \\
\text { more than } 50 \% \text { of shares are offered by the } \\
\text { state for sale }\end{array}$ \\
\hline SMALL / SF & Strategy for small firms & Over $80 \%$ of acquired shares are in small firms \\
\hline MED /MF & Strategy for medium size firms & $\begin{array}{l}\text { Over } 80 \% \text { of acquired shares are in medium } \\
\text { firms }\end{array}$ \\
\hline LARGE / LF & Strategy for large firms & Over $80 \%$ of acquired shares are in large firms \\
\hline DIS / D & $\begin{array}{l}\text { Strategy for locational concentration in } \\
\text { one district }\end{array}$ & $\begin{array}{l}\text { Over } 80 \% \text { of acquired shares are in firms from } \\
\text { one district }\end{array}$ \\
\hline IND / I & $\begin{array}{l}\text { Strategy for concentration in one } \\
\text { industry }\end{array}$ & $\begin{array}{l}\text { Over } 80 \% \text { of acquired shares are in firms from } \\
\text { one industry }\end{array}$ \\
\hline
\end{tabular}

The further analysis of the data showed that almost each of our strategies has been applied by some funds. There were also funds without specific strategy, and funds with multiple strategies (Table 4.). The strategy of concentration of investments has been applied by 27 funds of large and medium size. Amongst these are the 3 extra-large funds, 1 small, and 2 micro funds. However the total value of shares acquired by funds applying this strategy, is 46,825,340, which represents $67,73 \%$ percent of the total value of acquired shares during the mass privatisation program.

The next most popular strategy, applied by funds, is the strategy for asset management. It is used by 53 funds, and they have acquired in total 43,806,978 shares, which is $63,37 \%$ percent of the total value of acquired shares during the mass privatisation program. The group of funds that applied management strategy includes the 3 extra-large funds, 9 large funds, 19 medium, 13 small, and 9 micro funds. This is clearly one of the most popular investment strategy, as it is applied by almost all of the funds with the exception of two of them (Semeen and Nikotiana) and the group of the Citizens. Semeen privatisation fund has opted out for a strong control strategy, while the Nikotiana privatisation fund has attempted to realise simultaneously strong concentration and industrial strategy, and a marginal strategy for large firms.

The strong control strategy, was applied also by 53 funds. The total number of shares acquired with this strategy is $23,624,586$, which is equivalent to $34,17 \%$ percent of the total value of acquired shares during the mass privatisation program. The group of funds with strong control strategy includes 2 extra-large, 3 large, 21 medium, 16 small, and 11 micro funds. On the same category, the number of funds with marginal control strategy (more that $50 \%$ of their portfolio is invested in shares in firms with potential control) reaches the total of 74 funds.

Amongst the 8 exceptions of funds that have aimed at investing in firms with potential control are 2 large funds (Multigroup and Neftohim), 3 medium funds, 1 small and 2 micro funds. Overall the large and medium funds in this small group of exceptions from the trend for control have applied a strong concentration and asset management strategy, the medium funds have also applied strong to marginal industry and district strategy, while the small and the micro funds have opted only for a marginal industry strategy. 
Table 5. Strategic Orientation of Privatisation Funds

\begin{tabular}{|c|c|c|c|c|c|c|c|c|c|c|c|}
\hline Privatisation fund & $\begin{array}{c}\text { Differences between } \\
\text { total average and } \\
\text { acquired shares from } \\
\text { particular fund in \% }\end{array}$ & $\begin{array}{c}\text { \% of shares } \\
\text { for asset } \\
\text { management }\end{array}$ & $\begin{array}{l}\% \text { of } \\
\text { Shares } \\
\text { in } \\
\text { Control } \\
\text { Firms } \\
\end{array}$ & $\begin{array}{c}\text { \% of } \\
\text { shares in } \\
\text { SM }\end{array}$ & $\begin{array}{c}\text { \% of } \\
\text { shares in } \\
\text { MF }\end{array}$ & $\begin{array}{c}\text { \% of } \\
\text { shares } \\
\text { in LF }\end{array}$ & $\begin{array}{c}\text { \% of } \\
\text { shares in } \\
\text { 1D }\end{array}$ & District & $\begin{array}{c}\% \text { of } \\
\text { shares } \\
\text { in } 11\end{array}$ & Industry & Strategy \\
\hline \multirow{5}{*}{ 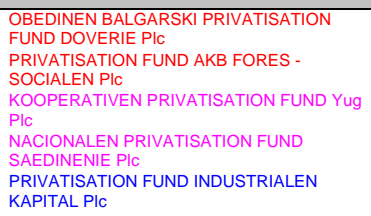 } & $147.08 \%$ & $91.91 \%$ & $82.24 \%$ & $41.91 \%$ & $44.23 \%$ & $13.86 \%$ & $17.61 \%$ & Sofia obl. & $16.11 \%$ & Machine-building & aaConc, Contr,Man, \\
\hline & $267.27 \%$ & $95.00 \%$ & $85.28 \%$ & $18.81 \%$ & $19.27 \%$ & $61.92 \%$ & $47.29 \%$ & Varna & $46.96 \%$ & Petro-chemical & aaConc, Contr,Man, \\
\hline & $147.19 \%$ & $88.64 \%$ & $95.41 \%$ & $32.75 \%$ & $45.40 \%$ & $21.84 \%$ & $33.54 \%$ & Sofia obl. & $35.51 \%$ & Machine-building & aaConc,Contr,Man, \\
\hline & $103.44 \%$ & $94.92 \%$ & $84.41 \%$ & $71.93 \%$ & $28.07 \%$ & $0.00 \%$ & $54.21 \%$ & Plovdiv & $26.19 \%$ & Machine-building & aaConc, Contr,Man, \\
\hline & $155.89 \%$ & $81.73 \%$ & $94.13 \%$ & $37.32 \%$ & $62.68 \%$ & $0.00 \%$ & $26.16 \%$ & Haskovo & $61.31 \%$ & Machine-building & aaConc, Contr, Man, \\
\hline PRIVATISATION FUND NASH DOM PIC & $147.07 \%$ & $90.96 \%$ & $90.78 \%$ & $56.36 \%$ & $38.08 \%$ & $5.56 \%$ & $30.60 \%$ & Varna & $33.86 \%$ & Food-processing & aaConc, Contr,Man, \\
\hline PRIVATISATION FUND ENERGOINVEST PIC & $137.77 \%$ & $98.20 \%$ & $100.00 \%$ & $57.09 \%$ & $42.91 \%$ & $0.00 \%$ & $33.11 \%$ & Montana & $42.91 \%$ & Trade\&services & aaConc, Contr,Man, \\
\hline PRIVATISATION FUND VARNA - PIC & $136.96 \%$ & $84.95 \%$ & $87.34 \%$ & $54.45 \%$ & $32.89 \%$ & $12.66 \%$ & $89.05 \%$ & Varna & $32.89 \%$ & TransportShip & aaConc, Contr,Man, Dis \\
\hline INDUSTRIALEN PRIVATISATION FUND PIC & $126.65 \%$ & $99.99 \%$ & $99.99 \%$ & $16.43 \%$ & $83.57 \%$ & $0.01 \%$ & $51.91 \%$ & Lovech (Pleven) & $51.91 \%$ & Paper & aaConc, Contr,Man,Mid \\
\hline PRIVATISATION FUND MIZIA PIC & $113.64 \%$ & $87.86 \%$ & $100.00 \%$ & $33.73 \%$ & $66.27 \%$ & $0.00 \%$ & $100.00 \%$ & Russe (turgovishte) & $66.27 \%$ & Electrical & aaConc,Contr,Man,Dis \\
\hline PRIVATISATION FUND ELEKTRONIKA & $229.51 \%$ & $99.91 \%$ & $100.00 \%$ & $0.00 \%$ & $100.00 \%$ & $0.00 \%$ & $99.91 \%$ & Sofia & $99.91 \%$ & Electrical & aaConc,Contr,Man,In,Dis, Mid \\
\hline \multirow{3}{*}{$\begin{array}{l}\text { PRIVATISATION FUND PETROL FOND PIC } \\
\text { OBEDINEN NACIONALEN PRIVATISATION } \\
\text { FUND ZLATEN LEV PIC } \\
\text { PRIVATISAIIN FUND SEVERKOOP. } \\
\text { GAMZA PIC }\end{array}$} & $282.25 \%$ & $78.90 \%$ & $61.06 \%$ & $21.78 \%$ & $46.71 \%$ & $31.51 \%$ & $35.01 \%$ & Sofia & $32.39 \%$ & Petro-chemical & aConc \\
\hline & $176.46 \%$ & $58.07 \%$ & $52.66 \%$ & $27.55 \%$ & $38.76 \%$ & $33.69 \%$ & $16.25 \%$ & Haskovo & $29.57 \%$ & Petro-chemical & aConc \\
\hline & $166.21 \%$ & $70.73 \%$ & $69.31 \%$ & $32.45 \%$ & $24.89 \%$ & $42.66 \%$ & $27.55 \%$ & Sofia obl. & $30.67 \%$ & Machine-building & aConc \\
\hline PRIVATISATION FUND SVETA SOFIA PIC & $109.55 \%$ & $54.04 \%$ & $57.59 \%$ & $34.18 \%$ & $29.98 \%$ & $35.84 \%$ & $21.71 \%$ & Varna & $23.08 \%$ & Petro-chemical & aConc \\
\hline PRIVATISATION FUND OREL - INVEST PIC & $146.73 \%$ & $76.55 \%$ & $70.05 \%$ & $23.03 \%$ & $61.57 \%$ & $15.40 \%$ & $25.16 \%$ & Russe & $23.63 \%$ & Textile & aConc \\
\hline $\begin{array}{l}\text { BALGARO-HOLANDSKI PRIVATISATION } \\
\text { FUND PIC }\end{array}$ & $194.90 \%$ & $83.03 \%$ & $75.84 \%$ & $23.54 \%$ & $32.41 \%$ & $44.06 \%$ & $31.77 \%$ & Varna & $35.04 \%$ & Petro-chemical & aConc,Man, \\
\hline \multirow{2}{*}{$\begin{array}{l}\text { PRIVATISATION FUND MULTIGRUP ELIT PIC } \\
\text { MENIJPSKO-RBAOTICHESKK } \\
\text { PRIVATIISATION FUND TRUD I KAPITAL PIC }\end{array}$} & $514.83 \%$ & $96.23 \%$ & $17.32 \%$ & $11.69 \%$ & $13.04 \%$ & $75.27 \%$ & $39.91 \%$ & Varna & $49.20 \%$ & Tourism & aConc,Man, \\
\hline & $187.65 \%$ & $83.96 \%$ & $70.43 \%$ & $32.38 \%$ & $46.29 \%$ & $21.33 \%$ & $18.39 \%$ & Sofia obl. & $20.41 \%$ & Petro-chemical & aConc,Man, \\
\hline \multirow{2}{*}{$\begin{array}{l}\text { PRIVATISATION FUND Albena invest PlI } \\
\text { PRRVATISATION FUND NEFTOHIM - INVEST } \\
\text { PIC }\end{array}$} & $182.05 \%$ & $82.39 \%$ & $53.71 \%$ & $24.53 \%$ & $20.34 \%$ & $55.13 \%$ & $38.72 \%$ & Varna & $39.36 \%$ & Tourism & aConc,Man, \\
\hline & $326.87 \%$ & $99.07 \%$ & $24.54 \%$ & $15.47 \%$ & $15.52 \%$ & $69.02 \%$ & $63.40 \%$ & Burgas & $69.02 \%$ & Petro-chemical & aConc,Man, \\
\hline CENTRALEN PRIVATISATION FUND PIC & $188.24 \%$ & $83.74 \%$ & $76.89 \%$ & $14.00 \%$ & $38.87 \%$ & $47.13 \%$ & $23.92 \%$ & Plovdiv & $33.71 \%$ & Petro-chemical & aConc,Man, \\
\hline PRIVATISATION FUND KONTINENTAL PIC & $163.75 \%$ & $90.67 \%$ & $33.13 \%$ & $35.64 \%$ & $2.15 \%$ & $62.21 \%$ & $76.06 \%$ & Sofia obl. & $59.02 \%$ & Metalurgy\&extraction & aConc,Man, \\
\hline PF NIKOTIANA - BT PIC & $155.01 \%$ & $24.55 \%$ & $1.87 \%$ & $7.45 \%$ & $41.78 \%$ & $50.77 \%$ & $44.75 \%$ & Sofia & $98.13 \%$ & Tabacco & aConc,Ind., \\
\hline \multirow{2}{*}{$\begin{array}{l}\text { PRIVATISATION FUND BALGARIA PIC } \\
\text { PRIVATSATION FUND SLANCHEV BRYAG } \\
\text { PRIVATINVEST PIC }\end{array}$} & $141.83 \%$ & $85.63 \%$ & $71.26 \%$ & $29.84 \%$ & $42.37 \%$ & $27.79 \%$ & $35.66 \%$ & Varna & $25.57 \%$ & Machine-building & aConc,Man,In,Dis,Lar \\
\hline & $117.36 \%$ & $100.00 \%$ & $16.13 \%$ & $16.13 \%$ & $0.00 \%$ & $83.87 \%$ & $89.33 \%$ & Burgas & $83.87 \%$ & Tourism & aConc,Man,In,Dis,Lar \\
\hline PRIVATISATION FUND IZGREV PIC & $151.42 \%$ & $73.48 \%$ & $0.00 \%$ & $0.00 \%$ & $100.00 \%$ & $0.00 \%$ & $73.48 \%$ & Burgas & $73.48 \%$ & Wood-processing & aConc,Mid., \\
\hline
\end{tabular}


MEL INVEST - PRIVATISATION FUND PIC PF RAZVITIE PIC

NAPREDAK PRIVATISATION FUND PIC

PRIVATISATION FUND BULSTRAD PIC

NACIONALEN PRIVATISATION FUND TRAKIA PIC FUND PIC

PRIVATISATION FUND PATISHTA PIC

PRIVATISATION FUND Marica - yug PIC

PRIVATISATION FUND RUEN PIC

PRIVATISATION FUND SIKONKO - INVEST PIC

PRIVATISATION FUND REPUBLIKA P

PRIVATISATION FUND BALGARSKI ZHELEZNICI PIC

REGIONALEN PRIVATISATION FUND SILA PIC Nacionalen PRIVATISATION FUND TRANSPORT PIC
INDSSTILLNO-AGRAREN PRIVATISATION FUND
VIVESTAPIO Severozapaden obedinen PRIVATISATION FUND

PRIVATISATION FUND Ekolinvest PIC

PRIVATISATION FUND INDUSTRIA PIC

PF BULINVEST - GRUP PIC

OBEDINEN AGRARNO-INDUSTRIALE
PRIVATIIATION FUND ZENIT PIC

PRIVATISATION FUND KOOPERATOR PIC

PRIVATISATION FUND EKIP P

RUSENSKI PRIVATISATION FUND - PIC

PRIVATISATION FUND RODINA PIC

PRIVATISATION FUND MERIDIAN PIC

PRIVATISATION FUND LOZENEC - KONSULT PIC
RALKANSKI PRIVATISATION FUND MIZIA - TRA MAKEDONIA PIC

PRIVATISATION FUND MNK - invest PI

\begin{tabular}{c|r|r|r|r|r|r|r|c|c|c|}
\hline $84.29 \%$ & $89.94 \%$ & $97.27 \%$ & $66.19 \%$ & $31.17 \%$ & $2.65 \%$ & $20.99 \%$ & Lovech & $49.48 \%$ & Food-processing & bContr,Man., \\
\hline $86.67 \%$ & $92.20 \%$ & $95.39 \%$ & $62.70 \%$ & $34.20 \%$ & $3.10 \%$ & $46.39 \%$ & Lovech & $25.84 \%$ & Textile & bContr,Man., \\
\hline $98.28 \%$ & $96.27 \%$ & $100.00 \%$ & $64.12 \%$ & $35.88 \%$ & $0.00 \%$ & $47.79 \%$ & Lovech & $41.30 \%$ & Machine-building & bContr,Man., \\
\hline $89.53 \%$ & $80.09 \%$ & $100.00 \%$ & $66.11 \%$ & $33.89 \%$ & $0.00 \%$ & $40.44 \%$ & Lovech & $32.24 \%$ & Textile & bContr,Man., \\
\hline $77.56 \%$ & $91.60 \%$ & $100.00 \%$ & $63.84 \%$ & $36.16 \%$ & $0.00 \%$ & $73.75 \%$ & Plovdiv & $39.11 \%$ & Machine-building & bContr,Man., \\
\hline $62.53 \%$ & $84.43 \%$ & $90.87 \%$ & $87.77 \%$ & $3.56 \%$ & $8.67 \%$ & $35.45 \%$ & Varna & $30.44 \%$ & Machine-building & bContr,Man., \\
\hline $86.56 \%$ & $98.87 \%$ & $97.87 \%$ & $75.38 \%$ & $24.62 \%$ & $0.00 \%$ & $31.09 \%$ & Lovech & $42.33 \%$ & Transport & bContr,Man., \\
\hline $43.17 \%$ & $82.74 \%$ & $98.33 \%$ & $39.87 \%$ & $60.13 \%$ & $0.00 \%$ & $55.53 \%$ & Lovech & $63.74 \%$ & Food-processing & bContr,Man., \\
\hline $65.34 \%$ & $81.53 \%$ & $100.00 \%$ & $84.40 \%$ & $15.60 \%$ & $0.00 \%$ & $33.30 \%$ & Sofia & $47.32 \%$ & Construction & bContr,Man., \\
\hline $61.07 \%$ & $84.81 \%$ & $100.00 \%$ & $85.93 \%$ & $14.07 \%$ & $0.00 \%$ & $49.45 \%$ & Lovech & $19.94 \%$ & Construction & bContr,Man., \\
\hline $76.32 \%$ & $81.72 \%$ & $100.00 \%$ & $70.50 \%$ & $29.50 \%$ & $0.00 \%$ & $39.50 \%$ & Haskovo (Stzagora) & $29.50 \%$ & Machine-building & bContr,Man., \\
\hline $6.92 \%$ & $93.87 \%$ & $100.00 \%$ & $48.83 \%$ & $51.17 \%$ & $0.00 \%$ & $56.45 \%$ & Lovech (Gabrovo) & $48.64 \%$ & Textile & bContr,Man., \\
\hline $65.21 \%$ & $81.17 \%$ & $97.65 \%$ & $81.17 \%$ & $16.49 \%$ & $2.35 \%$ & $54.24 \%$ & Plovdiv (Pazardzik) & $48.11 \%$ & Petro-chemical & bContr.Man., \\
\hline & & & & & & &
\end{tabular}

\begin{tabular}{|c|c|c|c|c|c|c|c|c|c|c|}
\hline $47.37 \%$ & $83.06 \%$ & $96.19 \%$ & $96.76 \%$ & $3.24 \%$ & $0.00 \%$ & $45.55 \%$ & Plovdiv & $84.74 \%$ & Transport & bContr,Man.,In,Sm \\
\hline $49.82 \%$ & $88.62 \%$ & $99.49 \%$ & $92.53 \%$ & $7.47 \%$ & $0.00 \%$ & $27.83 \%$ & Lovech & $58.63 \%$ & Machine-building & bContr,Man.,Small, \\
\hline $59.40 \%$ & $94.94 \%$ & $88.72 \%$ & $70.44 \%$ & $29.56 \%$ & $0.00 \%$ & $100.00 \%$ & Montana & $47.40 \%$ & Machine-building & bContr,Man.,Dist., \\
\hline $49.79 \%$ & $93.23 \%$ & $82.55 \%$ & $100.00 \%$ & $0.00 \%$ & $0.00 \%$ & $83.15 \%$ & Montana & $40.22 \%$ & Food-Processing & bContr,Man.,Dist.,Small \\
\hline $81.60 \%$ & $86.84 \%$ & $87.98 \%$ & $50.73 \%$ & $49.27 \%$ & $0.00 \%$ & $81.49 \%$ & Lovech & $97.39 \%$ & Machine-building & bContr,Man.,Ind.,Dist., \\
\hline $57.35 \%$ & $95.25 \%$ & $100.00 \%$ & $100.00 \%$ & $0.00 \%$ & $0.00 \%$ & $24.43 \%$ & Russe & $34.97 \%$ & Construction & bContr,Man.,Small, \\
\hline $55.98 \%$ & $99.01 \%$ & $86.77 \%$ & $99.03 \%$ & $0.97 \%$ & $0.00 \%$ & $38.19 \%$ & Haskovo & $37.22 \%$ & Construction & bContr,Man.,Small, \\
\hline $41.36 \%$ & $94.13 \%$ & $94.67 \%$ & $100.00 \%$ & $0.00 \%$ & $0.00 \%$ & $35.90 \%$ & Russe & $31.38 \%$ & Transport & bContr,Man.,Small, \\
\hline $54.08 \%$ & $84.37 \%$ & $84.39 \%$ & $84.37 \%$ & $0.02 \%$ & $15.61 \%$ & $100.00 \%$ & Sofia & $57.74 \%$ & Textile & bContr,Man.,Dist., \\
\hline $30.75 \%$ & $81.79 \%$ & $98.05 \%$ & $100.00 \%$ & $0.00 \%$ & $0.00 \%$ & $98.79 \%$ & Russe & $57.30 \%$ & Construction & bContr,Man.,Dist.,Sm \\
\hline $21.92 \%$ & $87.78 \%$ & $96.81 \%$ & $100.00 \%$ & $0.00 \%$ & $0.00 \%$ & $96.73 \%$ & Plovdiv & $37.18 \%$ & Wood-processing & bContr,Man.,Dist.,Small \\
\hline $46.31 \%$ & $84.47 \%$ & $80.48 \%$ & $90.65 \%$ & $9.35 \%$ & $0.00 \%$ & $43.31 \%$ & Sofia obl. & $32.99 \%$ & Machine-building & bContr,Man.,Small, \\
\hline $31.19 \%$ & $90.94 \%$ & $98.83 \%$ & $91.56 \%$ & $1.39 \%$ & $7.05 \%$ & $53.24 \%$ & Sofia & $36.64 \%$ & Construction & bContr,Man.,Small, \\
\hline $34.21 \%$ & $100.00 \%$ & $90.27 \%$ & $100.00 \%$ & $0.00 \%$ & $0.00 \%$ & $37.42 \%$ & Montana & $47.53 \%$ & Food-Processing & bContr,Man.,Small, \\
\hline $62.01 \%$ & $81.64 \%$ & $100.00 \%$ & $100.00 \%$ & $0.00 \%$ & $0.00 \%$ & $81.64 \%$ & Plovdiv & $81.64 \%$ & Tourism & bContr,Man.,In., Dis., Sm \\
\hline
\end{tabular}


PRIVATISATION FUND DOBRUJA PIC PRIVATISATION FUND SEVER - PIC PRIVATISATION FUND NOV VEK PIC

PRIVATISATION FUND STROYINVEST PIC FARMSTARINVEST - PRIVATISATION FUND PIC PRIVATISATION FUND SIGURNOST PIC

PF VAZRAZHDANE PIC

SEMEEN PRIVATISATION FUND PIC PIC GARANT INVEST - PRIVATISATION FUND PRIVATISATION FUND IZOTSERVIZ PIC PRIVATISATION FUND CENTAR PIC YUGOIZTOCHEN PRIVATISATION FUND PIC PRIVATISATION FUND BULGARIZING PIC NACIONALEN FARMACEVTICHEN PRIVATISATION

ARMEYSKI PRIVATISATION FUND PIC NACIONALEN PRIVATISATION FUND SVETI NIKOLA PRIVATISATION FUND BROD - PIC PF RODNA ZEMYA PIC

TOTAL CITIZENS PRIVATISATION FUND AKCIONER - FAVORIT PIC
NACIONALEN PRIVATISATION FUND NPICZHDA

PRIVATISATION FUND KOMPAKT PIC

PRIVATISATION FUND OTECHESTVO PIC

PF PLEVEN PIO

PRIVATISATION FUND - ASENOVA KREPOST, PIC PRIVATISATION FUND ZPICRUGA 21 VEK PIC

\begin{tabular}{|c|c|c|c|c|c|c|c|c|c|c|}
\hline $74.47 \%$ & $75.10 \%$ & $90.93 \%$ & $64.52 \%$ & $34.47 \%$ & $1.01 \%$ & $56.21 \%$ & Varna (Dobrich) & $29.48 \%$ & Machine-building & cContr, \\
\hline $66.87 \%$ & $66.63 \%$ & $88.23 \%$ & $61.73 \%$ & $20.05 \%$ & $18.22 \%$ & $49.82 \%$ & Lovech & $22.89 \%$ & Machine-building & cContr, \\
\hline $77.55 \%$ & $62.22 \%$ & $86.61 \%$ & $46.68 \%$ & $17.83 \%$ & $35.49 \%$ & $31.33 \%$ & Lovech & $30.32 \%$ & Electrical & cContr, \\
\hline $63.73 \%$ & $75.17 \%$ & $93.47 \%$ & $87.22 \%$ & $8.53 \%$ & $4.25 \%$ & $38.45 \%$ & Varna & $28.95 \%$ & Wood-processing & cContr, \\
\hline $55.52 \%$ & $74.51 \%$ & $85.41 \%$ & $63.43 \%$ & $36.57 \%$ & $0.00 \%$ & $79.70 \%$ & Sofia obl. & $20.13 \%$ & Shoe\&Leather & cContr, \\
\hline $60.74 \%$ & $64.72 \%$ & $91.17 \%$ & $66.03 \%$ & $0.00 \%$ & $33.97 \%$ & $34.56 \%$ & Lovech & $39.15 \%$ & Electrical & cContr, \\
\hline $80.93 \%$ & $61.40 \%$ & $99.39 \%$ & $72.50 \%$ & $27.50 \%$ & $0.00 \%$ & $40.73 \%$ & Sofia obl. & $32.54 \%$ & Machine-building & cContr, \\
\hline $34.31 \%$ & $31.15 \%$ & $99.98 \%$ & $31.65 \%$ & $68.33 \%$ & $0.02 \%$ & $34.90 \%$ & Russe (Razgrad) & $34.89 \%$ & Glass Industry & cContr, \\
\hline $43.51 \%$ & $74.90 \%$ & $100.00 \%$ & $81.04 \%$ & $18.96 \%$ & $0.00 \%$ & $65.24 \%$ & Kjustendil & $33.00 \%$ & Food-Processing & cContr, \\
\hline $37.68 \%$ & $53.24 \%$ & $87.66 \%$ & $54.72 \%$ & $45.28 \%$ & $0.00 \%$ & $61.33 \%$ & Sofia & $61.33 \%$ & Electrical & cContr, \\
\hline $60.88 \%$ & $69.20 \%$ & $94.61 \%$ & $89.65 \%$ & $10.35 \%$ & $0.00 \%$ & $87.20 \%$ & Haskovo (St.Zagora) & $28.21 \%$ & Textile & cContr,Dist., \\
\hline $29.36 \%$ & $63.20 \%$ & $97.41 \%$ & $91.73 \%$ & $8.27 \%$ & $0.00 \%$ & $46.26 \%$ & Burgas & $33.03 \%$ & Food-Processing & cContr,Small, \\
\hline $11.37 \%$ & $69.15 \%$ & $87.73 \%$ & $93.66 \%$ & $4.49 \%$ & $1.85 \%$ & $35.93 \%$ & Plovdiv & $53.94 \%$ & Textile & cContr,Small, \\
\hline $96.00 \%$ & $66.35 \%$ & $51.53 \%$ & $51.78 \%$ & $30.52 \%$ & $17.69 \%$ & $33.67 \%$ & Plovdiv & $85.02 \%$ & Chemic\&Pharmaceut & Ind., \\
\hline $76.88 \%$ & $93.91 \%$ & $66.09 \%$ & $39.64 \%$ & $32.11 \%$ & $28.25 \%$ & $47.01 \%$ & Haskovo & $30.18 \%$ & Textile & Man., \\
\hline $64.74 \%$ & $82.62 \%$ & $74.14 \%$ & $66.04 \%$ & $33.96 \%$ & $0.00 \%$ & $26.03 \%$ & Haskovo & $37.36 \%$ & Tourism & Man., \\
\hline $64.48 \%$ & $85.82 \%$ & $99.84 \%$ & $87.41 \%$ & $0.77 \%$ & $11.82 \%$ & $34.83 \%$ & Sofia obl. & $33.14 \%$ & Electrical & Man., \\
\hline $88.07 \%$ & $89.95 \%$ & $68.20 \%$ & $72.40 \%$ & $21.75 \%$ & $5.86 \%$ & $76.79 \%$ & Burgas & $21.75 \%$ & Petro-chemical & Man., \\
\hline $43.24 \%$ & $100.00 \%$ & $79.87 \%$ & $100.00 \%$ & $0.00 \%$ & $0.00 \%$ & $65.67 \%$ & Plovdiv & $85.80 \%$ & Textile & Man.,Ind.,Small \\
\hline & & & & & & & & & & \\
\hline $44.39 \%$ & $39.17 \%$ & $63.21 \%$ & $49.58 \%$ & $22.65 \%$ & $27.77 \%$ & $19.58 \%$ & Varna & $19.33 \%$ & Machine-building & \\
\hline $69.43 \%$ & $57.24 \%$ & $68.16 \%$ & $35.31 \%$ & $40.51 \%$ & $24.18 \%$ & $17.70 \%$ & Burgas & $27.96 \%$ & Machine-building & \\
\hline $95.70 \%$ & $65.17 \%$ & $63.20 \%$ & $24.46 \%$ & $62.54 \%$ & $12.99 \%$ & $21.20 \%$ & Lovech & $31.38 \%$ & Machine-building & \\
\hline $91.18 \%$ & $58.38 \%$ & $64.55 \%$ & $54.99 \%$ & $17.23 \%$ & $27.78 \%$ & $57.80 \%$ & Haskovo & $29.79 \%$ & Metalurgy\&extraction & \\
\hline $12.86 \%$ & $64.34 \%$ & $65.01 \%$ & $64.37 \%$ & $0.02 \%$ & $35.62 \%$ & $32.12 \%$ & Sofia & $32.11 \%$ & Tabacco & \\
\hline $53.94 \%$ & $75.07 \%$ & $71.40 \%$ & $76.91 \%$ & $23.09 \%$ & $0.00 \%$ & $72.24 \%$ & Lovech (Pleven) & $23.09 \%$ & Food-Processing & \\
\hline $56.02 \%$ & $71.06 \%$ & $20.59 \%$ & $20.59 \%$ & $59.51 \%$ & $19.90 \%$ & $72.86 \%$ & Plovdiv & $79.41 \%$ & Petro-chemical & \\
\hline $47.98 \%$ & $68.33 \%$ & $28.74 \%$ & $68.33 \%$ & $31.67 \%$ & $0.00 \%$ & $39.59 \%$ & Burgas & $50.41 \%$ & Food-Processing & \\
\hline $100.00 \%$ & & & & & & & & & & \\
\hline
\end{tabular}


The strong strategy for small firms has realised the acquisition of 3,531,888 shares, which is $5,11 \%$ percent of the total value of acquired shares during the mass privatisation program. The group includes 6 medium, 9 small and 9 micro funds. However, another 22 funds have shown a marginal strategy for small firms, where more than $50 \%$ of the investments have gone towards acquisition of assets in small firms.

The strategy for medium size firms have been very marginal, and only 1 medium and 2 small funds have adopted it. All three of them have also adopted industrial and district strategy. These are in the electronic industry, in paper, and in wood-processing industry. Only one medium size fund has adopted a strong strategy for acquiring shares in large firms. It also shows a strong concentration in one industry (tourism) and in one district (Burgas).

Twelve of the privatisation funds have adopted a strong district concentration, acquired in total 1,903,168 shares (2,75\% percent of the total value of acquired shares). Among them are 3 medium, 4 small, and 5 micro Funds. Another 19 funds have adopted a marginal district strategy, where above $50 \%$ of the acquired shares are in one district.

The strategy for industry concentration has been applied by 8 funds - 3 medium, 2 small and 3 micro. Within their group, they have acquired 1,593,107 shares, which is 2,30\% percent of the total value of acquired shares during the mass privatisation program. Another 14 funds have adopted a marginal industry strategy where above $50 \%$ of the acquired shares are in the same industry.

Overall, there are two main groups of portfolio investment strategies. One comprises of funds targeting shares for high concentration in firms, simultaneously with an asset management strategy. The other group comprises of funds targeting shares in firms, where there is a potential for establishment of private control, simultaneously with asset management strategy, and with strong small firm, district, or industry strategy.

There is also a small group of seven funds that have only marginal strategy for assets management and control, and have diversified widely their risk. Among them are 1 large, 2 medium, 3 small and 1 micro Funds, and the group of Citizens.

A large part of the privatisation funds in Bulgaria were subsequently transformed into holding companies rather than to remain as investment companies. These are mostly the funds that specialize in certain branches and industries. There are funds among them founded by persons with interests and experience in different and usually non-complementary spheres - for example pharmaceutics, tobacco industry, electronics, grains, flour manufacturing. This fragmentation of the portfolio reflects the loss of economies of scale through the economy.

The branch orientated funds which capture industrial efficiencies and the regional ones which capture locational efficiencies seem to strive more for control over the acquired enterprises and there could be expected that these funds will drain out profits at the entrance and the exit of the enterprises through other intermediary firms, connected to them. It is quite probable, that through transfer prices the profits will "flow out" into companies around the privatised ones. The objectives of some of the larger funds are somewhat different, namely: to restructure the enterprises and to increase their market value, after which the privatisation fund would sell the shares of this enterprise to another investor, thus realizing higher capital gains.

The strongest interest during the auctions was shown in the food, tourism, wine and tobacco industries - manufacturing of cooking oil, milk production, mills, fodder plants. (Table 6.) The second in rank are the pharmaceuticals, cosmetics and chemistry. Especially vigorous bidding was observed for the small and midium-sized enterprises in this branch. The enterprises 
from the woodworking branch, furniture production, paper and cellulose production, textile, knitwear industry, shoes manufacturing, cement, pottery, terracotta and glass production should also be added to the above ranking.

Table 6. Target Industry

\begin{tabular}{||c|l|c|}
\hline № & Target Industry & $\%$ \\
\hline 1. & Tourism & 15.2 \\
\hline 2. & Food, wine and tobacco industries & 14.4 \\
\hline 3. & Trade and services & 11.2 \\
\hline 4. & Agricultural sector & 9.7 \\
\hline 5. & Chemical industry & 6.3 \\
\hline 6. & Oil industry & 6.0 \\
\hline 7. & Construction & 5.3 \\
\hline 8. & Military industry & 4.4 \\
\hline 9. & Telecommunications & 3.4 \\
\hline 10. & Other industries & 3.7 \\
\hline 11. & Multiple industries & 19.4 \\
\hline
\end{tabular}

The privatization of the state-owned enterprises by investment vouchers became an important factor for the transformation of the state property into private one. Considerable legislative, methodical and informational activities were carried out by the specialized state bodies in order to accomplish it. About 450 thousand of the eligible persons or $15 \%$ of the voucher holders participated individually. These participants received investment vouchers for the value of about $10-11$ billion BGL, which represents $16 \%$ of the whole voucher capital acquired. The citizens, who participated individually in the centralized auctions, had passive behavior. They purchased 7465951 shares or about $9 \%$ of the determined shares of the stateowned enterprises (according to data from the Center for mass privatization).

It could be concluded, that the holders of investment vouchers have trusted their holdings to the 81 licensed privatization funds. This is due to the comparatively well-performed advertising and organization work by the privatisation funds during the period for accumulation of investment voucher capital from the citizens. The privatization funds have attracted more than 2,5 mil people, holders of voucher books, and have accumulated investment vouchers for more than 64 billion BGL, which represent $84 \%$ of the whole voucher capital of in Bulgaria.

\section{Conclusions}

What we have observed, is that each national government in eastern Europe while following the main recommendations on transition policy, has opted for specific solutions both as policy instruments, and as timing for their application. Restitution was conducted in four countries - the former Czechoslovakia, Poland, Hungary and Bulgaria. The auctioning of small companies was conducted in almost all of the central and east European countries. Spontaneous privatisation was a legal option only in Slovenia and Hungary. Mass privatisation, while conducted in almost all countries in the region, has significant differences in terms of instruments, allocated proportions for the state, responsible institutions and intermediaries of the type of privatisation investment funds. In addition, Hungary, the Czech Republic and Romania 
have offered their utilities for sale. The significant differences in the institutional framework for the privatisations have lead to a variety of outcomes - legal and administrative difficulties to constitute a new system of property rights.

The privatisation is a large-scale process with long-lasting economic, political and social consequences. The analysis of the alternative approaches, for the achievement of the general common objective - speed of the reform and justice in the de-appropriation - describes the contradictions in national regulation provisions between the objectives of the state and the interests of the investors. One side-effect in this process was the stimulated entrepreneurial activity in the economy - not only among investors, but also among other stakeholders in the economy, such as managers, employees, or other citizens.

The mass privatisation program in Bulgaria facilitated the development of corporate governance that involved over $3 \mathrm{mln}$ Bulgarian citizens with active influence on the capital market and the industrial sector of the economy. The privatization funds as intermediaries were established as the main institution. A new regulatory framework was established to regulate the relationships between capital markets, financial intermediaries and private investors.

The funds should not be considered as abstract financial intermediaries, whose only relation to the corresponding enterprise is the purchase of shares (this is the typical role of the investment funds in the U.S.A.). They should be considered as strategic investors that could provide foreign investment and changes in technologies and market relations to the privatised enterprises.

Some of the main conclusions, connected with the functioning of the privatisation and investment Funds, as a basic economic agents of the process of mass privatisation in Bulgaria are:

(1) The listing of firms across almost all industrial sectors of the economy encouraged the wide diversification of investment strategies.

(2) The regulation constraints upon the percent of the renewed shares of the subjected to privatisation enterprises (34\% in Bulgaria, 10\% in the Russian Federation etc.) lead to undercover agreements between the funds, or to incomplete representation of the funds into the management and the control bodies of the privatised companies.

Our analysis of the investment strategies adopted by the funds shows that they depend on the size of the fund and the insider information. We identified a wide diversity of investment strategies, applied in parallel combinations. We grouped them in 7 main groups (see Table 6). The predominant strategies applied by the funds are the concentration strategy - attracted $68 \%$ of the total value of shares - and asset management strategy - attracted $63 \%$ of the total value of shares. This suggests a strong interest for value maximisation through portfolio management. The dualistic character of the investment funds - holdings and investment companies - explains to certain extend the preferences for risk diversification.

The main groups describing the strategic orientation of the investment funds are the following (see Table 5):

1) Funds that have applied simultaneously strong concentration, asset management and control strategy. This groups resembles a mixture of funds from all sizes, with preferences for small and medium size firms in different sectors, diversifying the risk by simultaneously seeking concentration of holdings in firms and preferences for firms with potential majority ownership. 
2) Large funds that have applied strong concentration strategy only. This group comprises of large investment funds that were seeking concentration of holdings in selected large, medium and small firms with a particular interest in the petrochemical industry.

3) Funds that have applied only a strong concentration and asset management strategy. These are funds with a particular interest in large and medium size firms in the petrochemical industry and tourism, seeking concentration of their holdings for future market transactions, or for strong participation in the governance of the firms.

4) Funds that have applied only strong control and asset management strategy. In this group funds have opted for investment in selected small firms with moderate district and industry focus.

5) Funds that have applied a mixed strategy excluding concentration of holding. These are primarily small and medium size funds that have made very precise choices regarding their portfolio and acquiring significant holdings primarily in small and medium firms with potential control.

6) Funds that have applied either strong control, or strong asset management strategy focused on selected firms. This group differs from group 5 by their strong orientation for holdings in small firms.

7) Funds that are not associated with any particular strong strategic orientation. A small group of funds, including the group of individual citizens, have exhibited no strong orientation in their investment strategy, spreading their holdings between firms of different size, and in different industries and districts.

The very little emphasis that funds put on potential industrial and district dominance suggests that fund managers were not interested in direct management of the assets, and the benefits of locational and industrial efficiencies.

Ultimately the Bulgarian Mass Privatisation Program produced a large volume of single private firms owned simultaneously by different investment funds. The evolving governance structure and broken supplier linkages of these firms reduced their abilities to absorb market pressure. The transfer of property rights therefore was achieved at the expense of reduced flexibility of firms to respond to market signals. Our results highlight once again the mixed outcomes from the privatisation that took place in central and eastern Europe.

\section{Bibliography}

Boneva, I. (1997) Financial and Economic Conditiond of Enterprises and Reasons for their Privatisation, In: Finansii, no. 2, 1997.

Chavance, B. (1994) The Transformation of Communist Systems. Economic reform Since 1950s, Westview Press, Oxford.

Commercial Code (1991) Durzhaven Vestnik, no. 48/91, ammended in Durzhaven Vestnik 103/95.

Center for Mass Privatisation (1996) Catalog of the enterprises, included in the list for Mass Privatisation, Council of Ministers, Sofia.

Center for the Study of Democracy (1995) Mass Privatisation in the Reforming Countries, Sofia.

Frydman, R. and Rapaczynski, A. (1994) Privatisation in Eastern Europe: Is The State Withering Away? Central European University Press, London.

Institute of Commerce (1994) Privatisation in Germany, Hungary and Poland - Experience and Results, Sofia: Ministry of Commerce. 
International Center for Economic Development (1992) Privatisation in the Czech Republic, Sofia.

International Center for Economic Development (1992) Privatisation in Poland, Sofia.

Jezhek, T. (Ed.) (1995) Privatisation in the Czech and the Slovak Republics, Burgas: Delfin Press.

Kalaidgiev, A., Stancheva, V., Popov, T. (1996) Mass Privatisation: Privatisation Funds, Sofia: Trud I Pravo Publ.

Kotrba, J., Kocenda, E., Hanousek, J. (1999) 'The Governance of Privatisation Funds in the Czech Republic', In: Simoneti, M., Estrin, S., Bohm, A. (1999) The Governance of Privatisation Funds, Cheltenham, UK: Edward Elgar.

Law for Transformation and Privatisation of State and Municipal Enterprises (1992) Durzhaven Vestnik, no.38/92, amended in Durzhaven Vestnik no. 51/94., no. 45, 57, 109/95., no. 42, 45, 68, 85, 86 / 96., no. 55, 61, 89, 98, 122/ 1997., no. $39 / 1998$.

Law for the Privatisation Funds (1996) Durzhaven Vestnik, no.1/96, amendments in Durzhaven Vestnik, no.23/96.

Law for the Securities, Stock Exchanges and Investment Companies (1995) Durzhaven Vestnik, no. 63 / 1995., ammended in Durzhaven Vestnik, no. 68, 85 /96., no. 52, 90, 94, 98 /97., no. $42 / 98$.

Lewandowski, J., Szyszko, R. (1999) 'The Governance of Privatisation Funds in Poland', In: Simoneti, M., Estrin, S., Bohm, A. (1999) The Governance of Privatisation Funds, Cheltenham, UK: Edward Elgar.

Oresharski, P. et.al. (1995) Securities, Stock Exchanges and Investment Companies, Sofia: Trud Publ.

Porter, M. (1991) Towards a Dynamic Theory of Strategy, Strategic Management Journal, vol. 12, pp. 95-117.

Pari, weekly, No.41, Nov.28, 1997

Program for Privatisation with Investment Bonds, (1995) Durzhaven Vestnik, no. 76/95, amended бр.74/1996г.

Results from the First Wave of Mass Privatisation: Auctions 1, 2, 3. (1998) Center for Mass Privatisation, Sofia, Council of Ministers.

Simoneti, M., Estrin, S., Bohm, A. (1999) The Governance of Privatisation Funds, Cheltenham, UK: Edward Elgar.

Statute Book for the Establishment of the Center for Mass Privatisation (1994) Durzhaven Vestnik, no.68/94, ammended in Durzhaven Vestnik, no. 85/95.

Stark, D. et al., (1990) Privatisation in Hungary: From Plan to Market or From Plan to Clan?

Todeva, E. (1996) Dynamics of Management Practices in Eastern Europe: The Case of Bulgaria. Journal for East European Management Studies, no. 4, pp. 47-70.

Welfens,P. and Jasinski, P. (1994) Privatisation and Foreign Direct Investment in Transforming Economies. Dartmouth, Aldershot, UK.

Zhekova, I., Rashkova, G. (1997) Privatisation - International Experience and Bulgarian Practice, Sofia. 